EUROPA REGIONUM TOM XXVIII ROK 2016

DOI: $10.18276 /$ er.2016.28-03

\author{
HANNA BORUCIŃSKA-BIEŃKOWSKA \\ Uniwersytet Zielonogórski
}

\title{
Obszary przyrodnicze a rozwój turystyki w gminach powiatu poznańskiego
}

\section{Wprowadzenie}

0 bszary o szczególnych walorach przyrodniczych, objęte ochroną prawną zajmują istotną pozycję w kształtowaniu systemów przyrodniczych całych obszarów funkcjonalno-przestrzennych, obejmują znaczną część przyrody ożywionej i nieożywionej. Dla województwa wielkopolskiego stanowią 35,6\% jego powierzchni (29 $826 \mathrm{~km}^{2}$, rys.1) $)^{1}$, są to: parki narodowe (Wielkopolski Park Narodowy), parki krajobrazowe i obszary chronionego krajobrazu. Na obszarze Wielkopolski występują także rezerwaty przyrody oraz pomniki przyrody, które często zlokalizowane są na ww. terenach objętych ochroną prawną. Parki krajobrazowe to tereny chronione nie tylko ze względu na znaczenie przyrodnicze, ale także historyczne, kulturowe i krajobrazowe. Na jednego mieszkańca województwa wielkopolskiego przypada $2718 \mathrm{~m}^{2}$ pow. przyrodniczych prawnie chronionych $^{2}$. Tereny te wpływają $\mathrm{w}$ dużym stopniu na jakość życia mieszkańców oraz na możliwości rozwoju, wielkość, rozkład i strukturę ruchu turystycznego. Ten dział gospodarki, dla wielu mieszkańców terenów gmin wiejskich będących w strefie oddziaływania dużego miasta, stanowi ważną dziedzinę rozwoju społeczno-gospodarczego. Natomiast obszary chronionego krajobrazu ze względu na szczególny krajobraz, o zróżnicowanych ekosystemach umożliwiają

\footnotetext{
${ }^{1}$ Województwo wielkopolskie - podregiony, powiaty, gminy 2015. Urząd Statystyczny w Poznaniu, Poznań 2015.

${ }^{2}$ Za: ibidem, s. 78.
} 
realizowanie zainteresowań turystycznych, rekreacyjnych i sportowych mogą także pełnić funkcje korytarzy ekologicznych. Na terenie gmin Poznańskiego Obszaru Metropolitalnego (POM) występują wszystkie formy ochrony przyrody w rozumieniu Ustawy o ochronie przyrody z 16 kwietnia 2004 r. (tekst jednolity DzU z 2013 r. poz. 627, z późn. zm.). Nie budują one jednak zwartych, wzajemnie uzupełniających się sieci powiązań, lecz występują jako „wyspy ekologiczne". Stanowi to istotny problem dla rozwoju funkcjonalno-przestrzennego terenów przyrodniczych zarówno chronionych prawem jak i nie objętych protekcją. W znaczący sposób wpływa na kształtowanie przez samorządy terytorialne oraz lokalne społeczności realnej i racjonalnej polityki równoważenia rozwoju obszarów przyrodniczych oraz może przyczyniać się do zmniejszenia odporności biologicznej obszarów funkcjonalnych.

Skala przebiegających w Polsce na przestrzeni ostatnich 25 lat zmian społeczno-gospodarczych wpłynęła na transformację funkcjonalno-przestrzenną, także terenów gmin wiejskich będących w strefie oddziaływania dużego miasta. Przekształceniom uległo środowisko przyrodnicze, w tym także tereny gruntów rolnych zmienione na mieszkaniowe i aktywizacji gospodarczej. Dotyczy to przede wszystkim procesów na obszarach analizowanych gmin stykowych do miasta centralnego, tworzących obszar metropolitalny. Szczególnie gminy I strefy oddziaływania Poznania utraciły swoją pierwotną funkcję z rolniczej $(\mathrm{R})$ poprzez rolniczo-usługową (R-U) na usługowo-rolniczą (U-R) z wiodącą funkcją mieszkaniową, aktywizacji gospodarczej, sportową, rekreacyjną i turystyczną. Prawidłowy rozwój oraz prosperowanie funkcji sportowych, rekreacyjnych i turystycznych jest możliwe przy harmonijnym funkcjonowaniu środowiska przyrodniczego, społecznego i gospodarczego. Rozszerzanie się miasta na tereny gmin bezpośrednio z nim sąsiadujących wpływa na zmiany funkcjonalno-przestrzenne obszarów przyrodniczych. Urynkowienie procesów gospodarczych, rozwój turystyki, swobodny dostęp do terenów sportowych i rekreacyjnych, budowa społeczeństwa obywatelskiego oraz przystąpienie Polski do Unii Europejskiej, przyczyniły się również do zmiany stylu, a także wzrostu poziomu życia mieszkańców gmin. Rozwijająca się świadomość proekologiczna władz samorządowych i lokalnych społeczności oraz rosnąca moda na mieszkanie w zdrowym środowisku przyrodniczym, wpłynęły na duże zainteresowanie mieszkańców miast terenami gmin wiejskich z nimi graniczącymi. Modernizacja, rozbudowa i budowa sieci powiązań komunikacyjnych spowodowały łatwiejszy dostęp do tych terenów. Ta bardzo pozytywna zmiana ilościowa i jakościowa, i dynamiczny rozwój infrastruktury technicznej na terenach wiejskich 


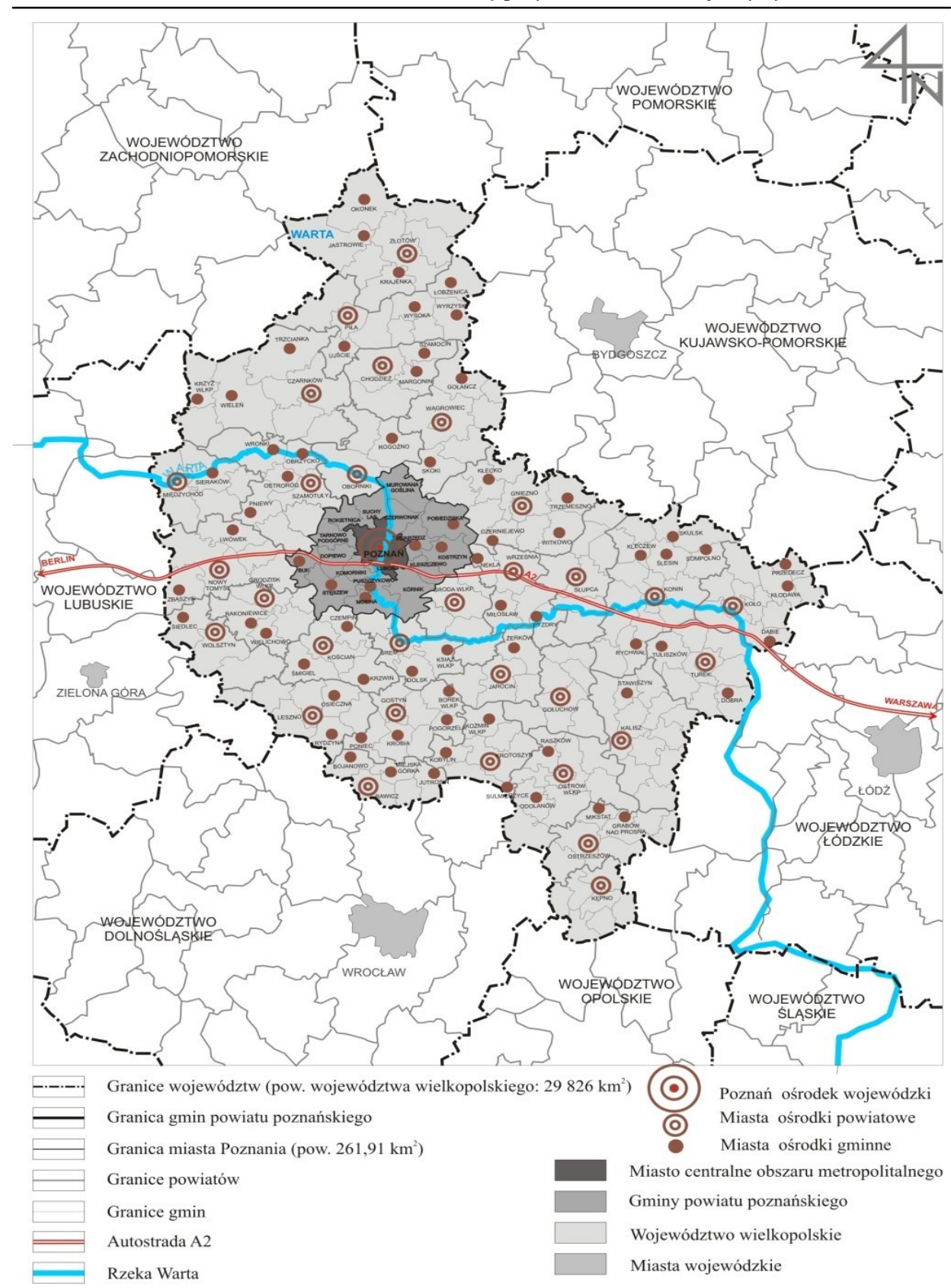

Rysunek 1. Gminy powiatu poznańskiego na tle układu administracyjnego województwa wielkopolskiego

Źródło: opracowanie własne na podstawie: Województwo wielkopolskie podregiony, powiaty, gminy 2011. Urząd Statystyczny w Poznaniu, Poznań 2011. 
umożliwiły zrównywanie poziomu oraz standardu życia na wsi do standardów miejskich. Powszechna możliwość dostępu do sieci energetycznej, wodociągowej, kanalizacyjnej, gazowej, sieci światłowodowej itp. oraz konkurencyjne ceny gruntów inwestycyjnych spowodowały dynamiczny proces rozbudowy terenów mieszkaniowych i aktywizacji gospodarczej na obszarach wiejskich gmin graniczących z miastem centralnym, gmin powiatu poznańskiego. Nastąpiła, trwająca do tej pory $\mathrm{z}$ różnym natężeniem depopulacja miasta centralnego. Zmiany społeczno-gospodarcze oraz funkcjonalno-przestrzenne terenów gmin, w sposób bezpośredni i pośredni oddziałują na rozwój funkcji turystycznych, sportowych i rekreacyjnych.

Transformacji podlegają przede wszystkim tereny sąsiadujące $\mathrm{z}$ miastem centralnym oraz dysponujące bogatym i atrakcyjnym środowiskiem przyrodniczym, historycznym i zasobami kultury materialnej. Gminy powiatu poznańskiego to: 2 gminy miejskie - Luboń i Puszczykowo, 8 gmin miejsko-wiejskich - Buk, Kostrzyn, Kórnik, Mosina, Murowana Goślina, Pobiedziska, Stęszew i Swarzędz oraz 7 gmin wiejskich - Czerwonak, Dopiewo, Kleszczewo, Komorniki, Rokietnica, Suchy Las, Tarnowo Podgórne. Migracja ludności z miasta centralnego na tereny gmin stykowych wpłynęły na skalę i tempo rozwoju różnych form działalności gospodarczej i aktywności społecznej. W latach 2000-2014 z Poznania ubyło 36574 mieszkańców, a na tereny gmin powiatu poznańskiego przybyły 98376 osoby $^{3}$. Proces migracji ludności spowodowany zmianami społeczno-gospodarczymi przyczynił się także do przekształceń funkcjonalnych, w tym również rozwoju funkcji turystycznych, sportowych i rekreacyjnych

\section{Zas oby środowis ka przyrodnicze go, his torycznego i kultury mate rialnej}

Lokalizacja $\mathrm{w}$ strefie oddziaływania dużego miasta ma wpływ na zmiany funkcjonalno-przestrzenne gmin z nim graniczących. O atrakcyjności turystycznej obszaru funkcjonalnego może decydować wiele czynników i uwarunkowań zarówno wewnętrznych jak i zewnętrznych. Do istotnych zaliczyć należy środowisko przyrodnicze, zasoby i stan obiektów historycznych oraz kultury materialnej. Znaczenie ma także świadomość władz samorządowych i lokalnych społeczności otwartych na możliwości rozwoju innych od dotychczasowych (rolniczych) dziedzin gospodarki.

${ }^{3}$ H. Borucińska-Bieńkowska, Proces urbanizacji terenów wiejskich gmin powiatu poznańskiego, Gliwice: Politechnika Śląska. Gliwice 2016. 


\subsection{Zasoby środowiska przyrodniczego - szanse i zagrożenia}

Gminy POM położone są na terenie młodoglacjalnego obszaru wysoczyzn jeziornych, w centralnej części województwa wielkopolskiego, w dorzeczu Warty (całkowita długość rzeki $808 \mathrm{~km})^{4}$, na Nizinie Wielkopolsko-Kujawskiej. Charakteryzują się dużą ilością jezior i stawów oraz gęstą siecią rzek i rowów, a także urozmaiconą rzeźbą terenu $\mathrm{z}$ licznymi wzniesieniami przeciętymi dolinami oraz polodowcowymi rynnami jezior. Na terenie miasta Poznań występują dwa jeziora polodowcowe: Jezioro Kierskie (288 ha) i Jezioro Strzeszyńskie (35 ha) dające atrakcyjne możliwości rozwoju turystyki o zasięgu lokalnym i ponadlokalnym. Jednym $\mathrm{z}$ podstawowych priorytetów w aspekcie środowiska naturalnego jest protekcja, utrwalanie, a także rozbudowa przestrzennych systemów przyrodniczych poprzez ochronę istniejącego stanu oraz realizację nowych zadrzewień i zalesień. Budowanie ciągłości systemów ekologicznych jest istotne dla tworzenia korytarzy stanowiących drogi migracji zwierząt i roślin. Podkreślić należy, że ww. korytarze powinny tworzyć ciągłe systemy w skali województwa, kraju i Europy, takie jak:

- ponadregionalne korytarze dolin rzecznych,

- regionalne korytarze dolin rzecznych,

- lokalne korytarze dolin rzecznych,

- ponadregionalne korytarze migracji ptaków i wymiany genetycznej organizmów żywych,

- regionalne korytarze migracji ptaków i wymiany genetycznej organizmów żywych,

- lokalne korytarze migracji ptaków i wymiany genetycznej organizmów żywych. W systemie korytarzy duże znaczenie mają także zadrzewienia śródpolne (wprowadzone po raz pierwszy na teren Wielkopolski w XIX w. przez Dezyderego Adama Chłapowskiego w Turwi) oraz nasadzenia wzdłuż tras komunikacyjnych.

W środowisku naturalnym ogromną rolę odgrywa woda. Dlatego tak istotna jest właściwa gospodarka jej zasobami, minimalizowanie zanieczyszczeń powierzchniowych i gruntowych oraz racjonalna polityka związana $\mathrm{z}$ retencją. Szczególnej ochronie muszą podlegać ujęcia wody, także ze względu na możliwe zagrożenie atakami terrorystycznymi. Występujące warunki klimatyczne oraz hydrologiczne na terenie gmin POM wpływają na okresowe niedobory wody,

${ }^{4}$ W. Lęcki, Przewodnik Wielkopolska, Sport i Turystyka Muza SA, Warszawa 1996, s. 23. 
dlatego tak duże znaczenie ma spójna polityka władz samorządowych oraz rosnąca świadomość ekologiczna lokalnych społeczności. Regulacja koryta rzeki Warty, rozszerzanie się miasta na tereny gmin stykowych oraz ich intensywna urbanizacja wpływa także na konieczność ochrony przeciwpowodziowej terenów zalewowych. Zagrożenie powodziowe na obszarach gmin POM nie jest duże, są one chronione przez zbiorniki retencyjne w Jeziorsku oraz m.in. Jezioro Kowalskie, Śródka, Iwno, Jezioro Maltańskie (70 ha) utworzone w 1952 r. przez spiętrzenie Cybiny ${ }^{5}$, a także naturalne poldery. Wielkopolska zalicza się do obszarów wyjątkowo korzystnych pod względem rolniczym z glebami o wysokiej bonitacji, dobrym klimatem oraz wysoką kulturą rolną. Gminy powiatu poznańskiego takie jak: Kleszczewo, Kostrzyn, Mosina, Stęszew, Komorniki mają najwyższą ocenę rolniczej przestrzeni produkcyjnej (rys. 2).

Jednak ze względu na lokalizację w strefie oddziaływania dużego miasta utraciły swój rolniczy charakter na rzecz rozwijających się innych dziedzin gospodarki. Gleby o najwyższej bonitacji oraz inne formy przyrody powinny być pod szczególną ochroną. Podlegają jednak silnej antropopresji i zmieniają swoją wiodącą funkcję. Proces ten występuje przede wszystkim na terenach analizowanych gmin stykowych do miasta centralnego, tworzących powiat poznański. Utraciły one swój pierwotny charakter $z$ rolniczego $(\mathrm{R})$ poprzez rolniczo-usługowy (R-U) na usługowo-rolniczy (U-R) z wiodącą funkcją mieszkaniową, aktywizacji gospodarczej, sportową, rekreacyjną i turystyczną. Zrównoważony rozwój terenów turystycznych, sportowych i rekreacyjnych jest możliwy przy harmonijnym funkcjonowaniu środowiska naturalnego, społecznego i gospodarczego.

Rozszerzanie się miasta na tereny gmin bezpośrednio z nim sąsiadujących wpływa na przekształcanie obszarów przyrodniczych, dlatego między innymi konieczna jest ich systemowa ochrona. Program Natura 2000 oraz ECONET przedstawia program sieci ekologicznych, które obejmują ochroną między innymi zagrożone siedliska przyrodnicze, rzadkie gatunki zwierząt i roślin. W Wielkopolsce wyznaczono obszary wskazane do objęcia ochroną, charakteryzujące się bogatym środowiskiem przyrodniczym. Ochronie podlegają lasy i zadrzewienia w granicach Poznania (4080 ha), które $\mathrm{z}$ doliną rzeki Warta tworzą system klinowo-pierścieniowy zieleni miasta. Jest on kontynuacją systemu klinowo-pierścieniowego zieleni miasta Poznań, który zostałopracowany przez Władysława Czarneckiego i Adama Wodziczko w okresie 20-lecia międzywojennego.

${ }^{5}$ Za: ibidem, s. 24 


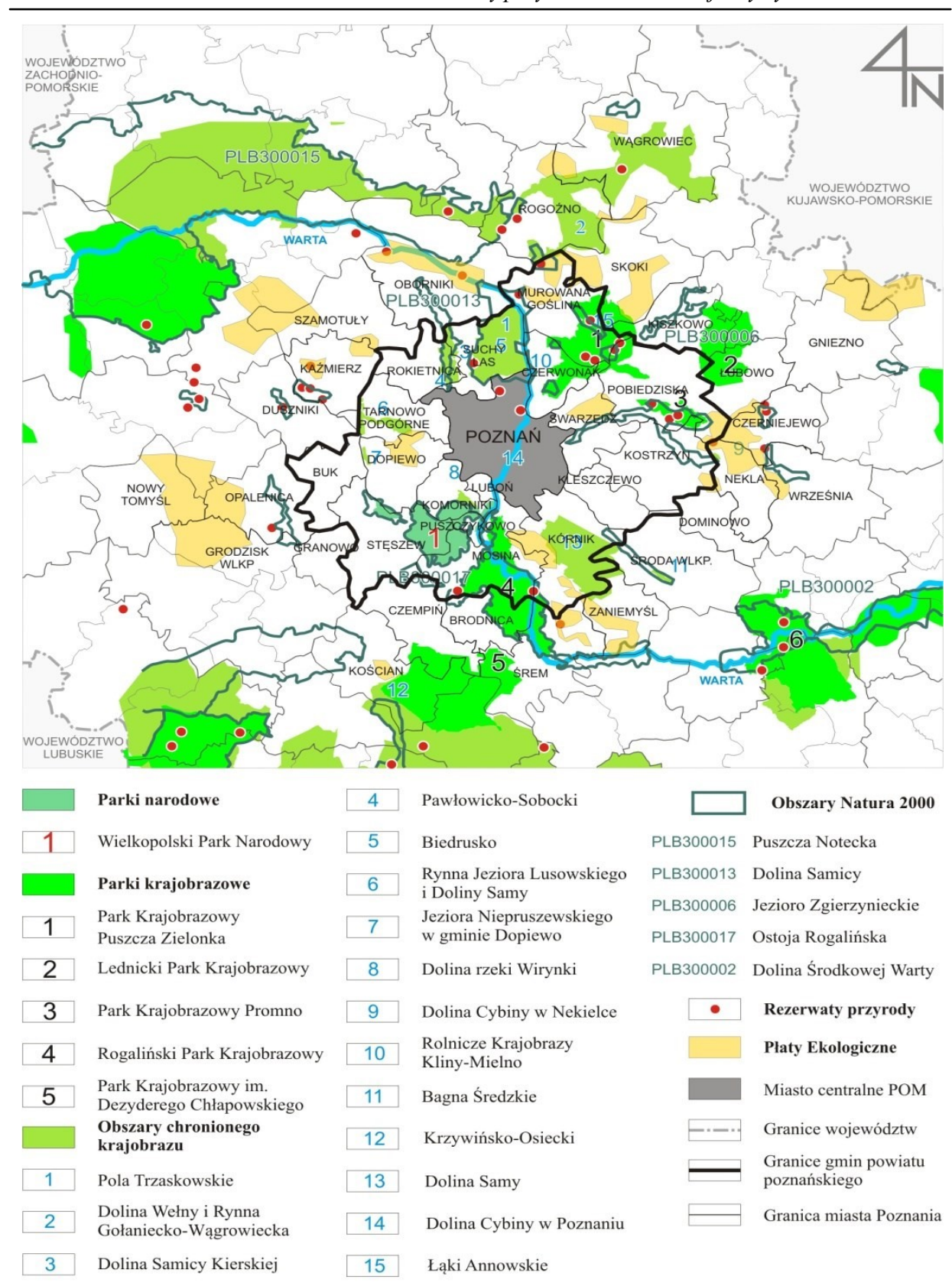

Rysunek 2 . Gminy powiatu poznańskiego - chronione obszary przyrodnicze

Źródło: opracowanie własne na podstawie: Założenia do planu zagospodarowania przestrzennego Poznański Obszar Metropolitarny, Urząd Marszałkowski Województwa Wielkopolskiego w Poznaniu, Poznań 2010. 
Gminą miejską powiatu poznańskiego o największym wskaźniku lesistości jest Puszczykowo. Program ochrony dolin rzecznych w Polsce oraz Natura 2000+ i ECONET-POLSKA zapewniają możliwości łączenia obszarów cennych przyrodniczo $\mathrm{w}$ jeden system funkcjonalno-przestrzenny lecz zróżnicowany przyrodniczo. System polegający na zachowaniu i kształtowaniu niezdegradowanych, naturalnych zasobów w celu utrzymania ciągłości procesów naturalnych np. poprzez tworzenie Leśnych Kompleksów Promocyjnych (LKP), które pełnią także funkcję edukacyjną i rekreacyjną. Jest to proces bardzo ważny szczególnie na terenach gmin powiatu poznańskiego, gdzie występuje silna antropopresja.

Rosnąca świadomość ekologiczna lokalnych społeczności oraz systemowe działania władz samorządowych $w$ celu równoważenia rozwoju sprzyjają m.in. promocji odnawialnych źródeł energii (OZE), a programy protekcji przyrody są wdrażane na poziomie lokalnym i ponadlokalnym. Obejmują także zagadnienia ochrony wody i gospodarki wodnej w gospodarstwach domowych. Wymuszają modernizację, rozbudowę lub budowę lokalnych ujęć wody, stacji uzdatniania wody, sieci przesyłowych oraz właściwą gospodarkę ściekami. Bezawaryjny odbiór ścieków oraz ich neutralizacja jest jednym z podstawowych zadań w celu zachowania równowagi biologicznej środowiska naturalnego. Poznański System Wodociągowy oparty jest na dwóch podstawowych ujęciach wody: ujęcie Dębina i ujęcie Swarzędz. Dostęp do wody pitnej dobrej jakości jest podstawą zrównoważonego rozwoju terenów zarówno mieszkaniowych jak i związanych z rozwojem turystyki, rekreacji i sportu. Zasoby wód powierzchniowych gmin powiatu poznańskiego są wykorzystywane zarówno przez rolnictwo, leśnictwo, jak i przemysł. Stanowią atrakcyjne środowisko dla rozwoju funkcji turystycznych, rekreacyjnych i sportowych oraz bazę dla organizacji wypoczynku codziennego, weekendowego i całorocznego zarówno dla mieszkańców Poznania, okolicznych gmin jak i turystów (rys. 3). 


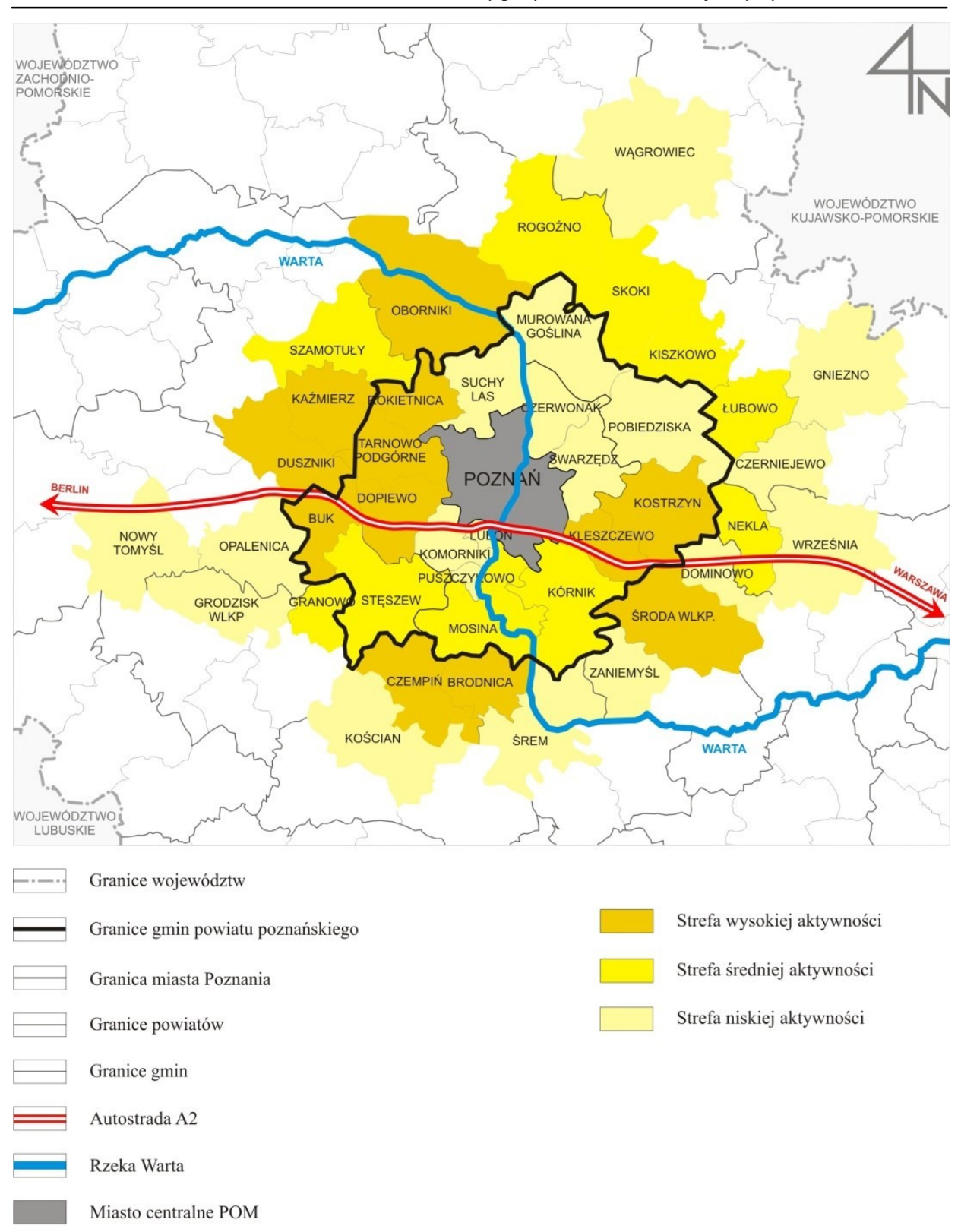

Rysunek 3. Gminy powiatu poznańskiego - obszary rozwoju funkcji rolniczych ze względu na potencjał rolny i występowanie gleb o wysokiej bonitacji

Źródło: opracowanie własne na podstawie: Rolnictwo województwie wielkopolskim w 2004, Urząd Statystyczny w Poznaniu, Poznań 205. 


\subsection{Zasoby środowiskahistorycznego i kultury - szanse i zagrożenia}

Środowisko przyrodnicze stanowi jeden z najbardziej istotnych elementów wpływających na rozwój turystyki, sportu i rekreacji. Połączone z zasobami historycznymi i kultury materialnej tworzy duży potencjał dla ww. dziedzin życia społecznego oraz istotnej gałęzi gospodarki. Środowisko historyczne i kulturowe to przede wszystkim obiekty zabytkowe, sakralne, układy urbanistyczne i ruralistyczne. Zbiory muzealne stanowiące dziedzictwo mieszkańców miast i wsi, pochodzące $\mathrm{z}$ różnych epok dają świadectwo historii, tradycji, kultury i związków gmin powiatu poznańskiego z Wielkopolską, Polską i Europą.

Najwięcej zabytków oraz zasobów kultury materialnej znajduje się w Poznaniu, który ma najwyższe znaczenie w województwie wielkopolskim. Na terenach gmin występują liczne obiekty sakralne i świeckie w zespołach urbanistycznych i ruralistycznych. Poza miastem centralnym, na terenie gmin powiatu poznańskiego na szczególną uwagę zasługuje zamek w Kórniku z arboretum, muzeum i biblioteką PAN. Początki tej rezydencji rodów Górków i Działyńskich sięgają średniowiecza, a obecny kształt pochodzi z XIX w., 11 lipca 2011 r. został uznany za pomnik historii Polski.

Barokowo-klasycystyczna rezydencja rodu Raczyńskich w Rogalinie ze zbiorami muzealnymi pokazuje bogactwo ziemiaństwa wielkopolskiego. $\mathrm{Na}$ szczególną uwagę zasługuje także założenie parkowe. W zespole pałacowym znajdują się między innymi kościół pw. św. Marcelina - dawna kaplica rodu Raczyńskich, w podziemiach której pochowany jest hrabia Edward Bernard Raczyński (w latach 1979-1986 prezydent RP na uchodźstwie) oraz wozownia z XVIII w. W pałacowej galerii malarstwa, stanowiącej oddział Muzeum Narodowego w Poznaniu znajdują się prace między innymi Olgi Boznańskiej, Juliana Fałata, Jana Matejki, Jacka Malczewskiego, Leona Wyczółkowskiego, Stanisława Wyspiańskiego ${ }^{6}$.

$\mathrm{Na}$ terenie gmin powiatu poznańskiego występują także liczne stanowiska archeologiczne, cmentarzyska wczesnośredniowieczne, a także mówiące wiele o historii kościoły murowane i drewniane, stanowiące ważny element krajobrazu wsi wielkopolskiej.

Tworzenie parków kulturowych i krajobrazowych oraz punktów i panoram widokowych może wpływać na polepszenie ochrony zasobów kultury material-

${ }^{6}$ Za: ibidem, s. 333-334. 
nej i niematerialnej, szczególnie na obszarach przeznaczonych na rozwój funkcji turystycznych i rekreacyjnych. Utrwalanie lokalnej tradycji oraz świadomości historycznej pozwoli na łączenie protekcji walorów środowiska przyrodniczego, a także historyczno-kulturowego w celu tworzenia spójnej i wspólnej polityki zrównoważonego rozwoju obszarów o funkcji turystyczno-rekreacyjnej.

Rozwój ww. funkcji tworzy możliwości przetrwania wielu obiektów historycznych. Renowacja, restauracja, modernizacja, adaptacja budynków i zespolów budynków do potrzeb turystycznych i/lub rekreacyjnych oraz rewitalizacja zespołów funkcjonalnych kreuje nowy potencjał, daje szansę przetrwania, a także funkcjonowania wielu obszarom i obiektom historycznym oraz kulturowym. Połączenie tych działań z walorami przyrodniczymi i krajobrazowymi jest potencjałem rozwoju oraz dobrego funkcjonowania turystyki lokalnej i ponadlokalnej $\mathrm{w}$ tym także o zasięgu międzynarodowym.

W celu ochrony cennych zasobów środowisk przyrodniczych, historycznych i kulturowych władze samorządowe oraz lokalne społeczności powinny już na etapie dokumentów strategicznych (studium uwarunkowań i kierunków zagospodarowania przestrzennego) oraz planistycznych (miejscowe plany zagospodarowania przestrzennego) wskazywać tereny i obiekty podlegające ochronie zgodnie z obowiązującymi ustawami. Między innymi z Ustawą z dnia 27 marca 2003 r. o planowaniu i zagospodarowaniu przestrzennym (DzU nr 380, poz. 717), Ustawą z 27 kwietnia 2001 r. Prawo o ochronie środowiska (DzU 08. 25. 150 z póź. zm.), Ustawą z 16 kwietnia 2004 r. o ochronie przyrody (DzU 09. 151. 1220 z póź. zm.), Ustawą z 23 lipca 2003 r. o ochronie zabytków i opiece nad zabytkami (DzU 03. 1621568 z późn. zm.), które to dokumenty określają i definiują (między innymi) cele i sposoby równoważenia rozwoju obszarów cennych przyrodniczo i kulturowo.

Rewaloryzowanie jeszcze istniejących założeń ruralistycznych, dworów ziemiaństwa wielkopolskiego, pałaców i założeń pałacowo-ogrodowych, zabudowań folwarcznych, zagród olenderskich, bamberskich, a także architektury sakralnej, kapliczek i krzyży przydrożnych, cmentarzy różnych wyznań na terenie gmin stykowych do miasta powinno należeć do jednych z podstawowych zadań samorządów terytorialnych.

Podkreślić należy, że walory środowiska naturalnego, w tym obszary dolin rzecznych oraz Natura 2000+ i ECONET-POLSKA oraz walory środowiska historycznego i zasobów kultury materialnej stwarzają razem dogodne warunki dla rozwoju turystyki i rekreacji. Zapewniają możliwości łączenia funkcji obsza- 
rów przyrodniczych $\mathrm{w}$ jeden system funkcjonalno-przestrzenny $\mathrm{z}$ obszarami historyczno-kulturowymi. Funkcje i walory ww. obszarów często wzajemnie się uzupetniają i wzbogacają (rys. 4).

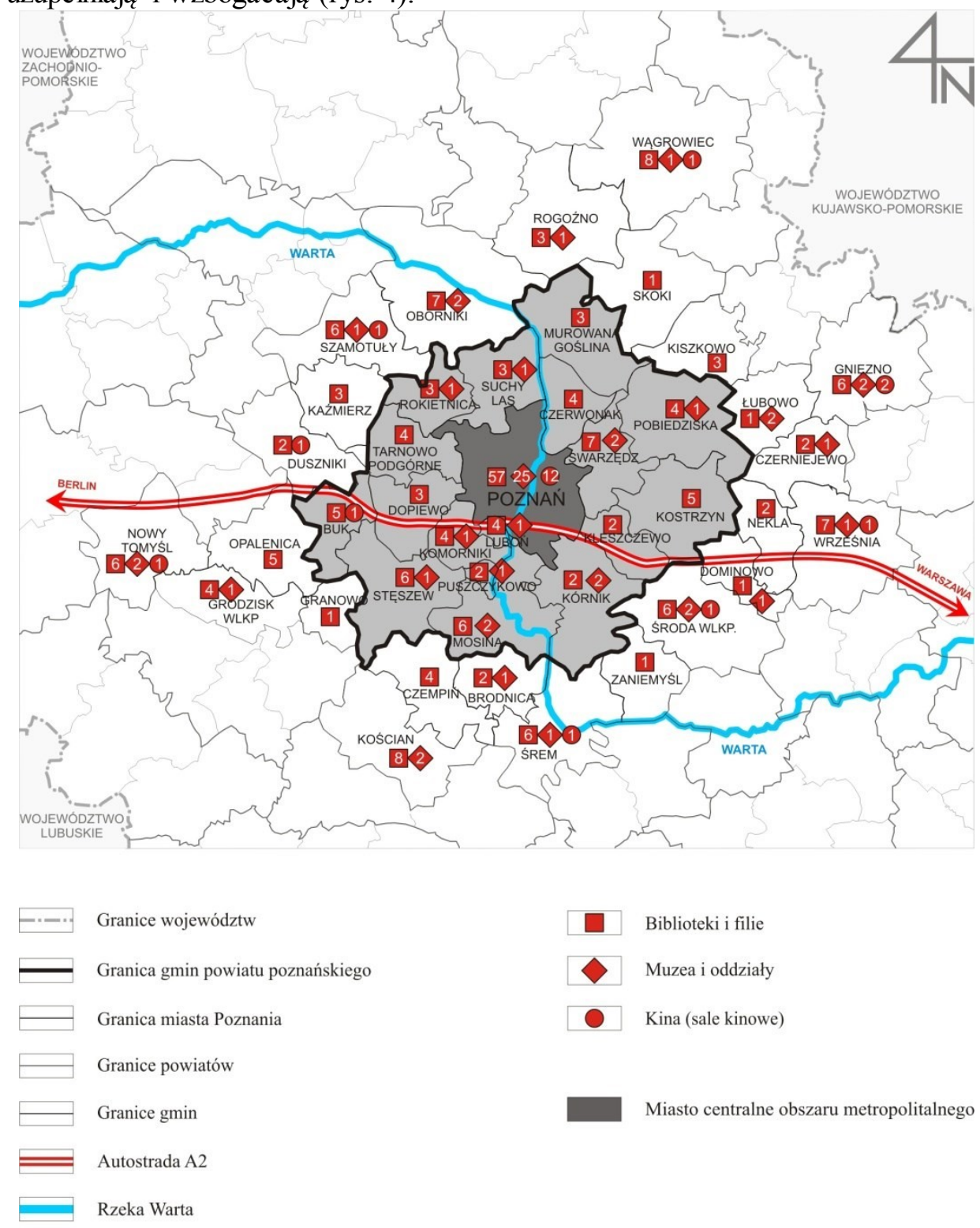

Rysunek 4. Gminy powiatu poznańskiego - zasoby kultury

Źródło: opracowanie własne na podstawie: Województwo wielkopolskie podregiony, powiaty, gminy 2011. Urząd Statystyczny w Poznaniu, Poznań 2011. 


\section{Ekologiczne, społeczne i ekonomiczneaspektyrozwoju turystykigmin}

W celu równoważenia rozwoju funkcji turystycznych gmin, czynniki ekologiczne, społeczne i ekonomiczne powinny wzajemnie się uzupetniać i przenikać.

Przede wszystkim środowisko przyrodnicze jest narażone na antropopresję z powodu rozwoju gospodarczego i transformacji funkcjonalno-przestrzennej gmin będących w strefie oddziaływania miasta centralnego. Dlatego tak istotne są czynniki ekologiczne, społeczne i ekonomiczne w procesie ww. przekształceń (rys. 5).

Do czynników ekologicznych można zaliczyć:

- formy ochrony przyrody (szczególnie wielkoobszarowe),

- urozmaicone środowisko rolniczo-leśno-łąkowe z dużą ilością wód powierzchniowych,

- zwarte tereny rolniczej przestrzeni produkcyjnej (gleby o wysokiej bonitacji),

- tereny dolin rzecznych,

- tereny lasów, łąk i pastwisk,

- lokalny krajobraz,

- klimat sprzyjający rozwojowi turystyki,

- zmianę profilu funkcji gmin ( $\mathrm{z}$ rolniczej $\mathrm{np}$. na turystycznorekreacyjną).

Do czynników społecznych możemy zaliczyć:

- potencjał demograficzny i saldo migracji,

- możliwości społeczno-gospodarcze,

- wzrost poziomu wykształcenia i świadomości ekologicznej,

- aktywność społeczną,

- rozwój społeczeństwa informacyjnego.

Do czynników ekonomicznych możemy zaliczyć:

- rozwój gospodarki rynkowej,

- bazę ekonomiczną mieszkańców,

- aktywność ekonomiczną,

- strukturę zatrudnienia,

- rozwój infrastruktury technicznej,

- rozwój komunikacji i transportu,

- dostępność bazy noclegowej i gastronomicznej. 


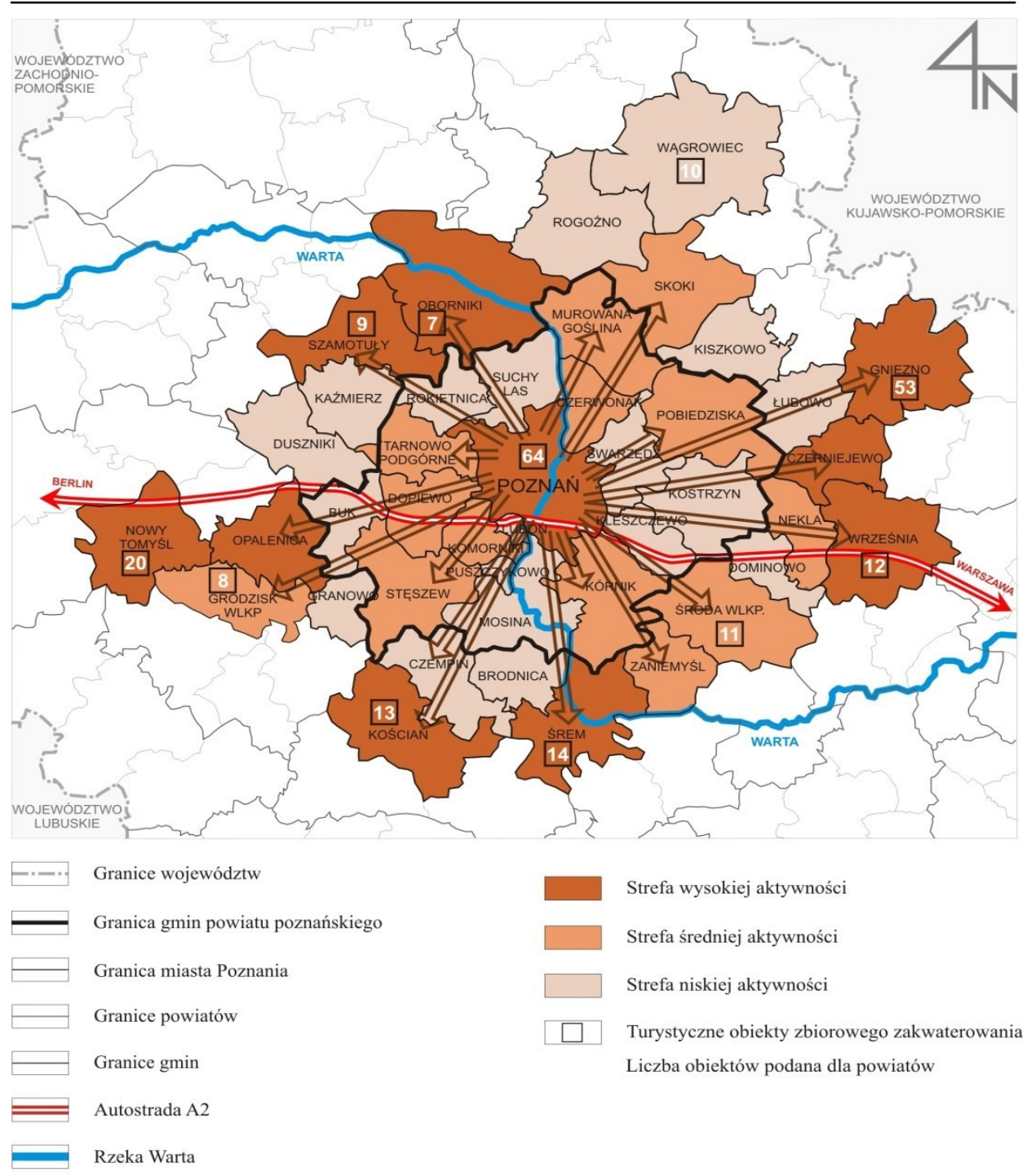

Rysunek 4. Kierunki rozwoju turystyki, sportu i rekreacji. Baza noclegowa, ośrodki i zaplecze turystyczne

Źródło: opracowanie własne na podstawie: Województwo wielkopolskie podregiony, powiaty, gminy 2011. Urząd Statystyczny w Poznaniu, Poznań 2011.

\section{Podsumowanie}

Transformacja społeczno-gospodarcza kraju po 1989 r. wpłynęła między innymi na rozwój ruchu turystycznego w skali lokalnej i ponadlokalnej. 
Wielkopolska stała się atrakcyjna dla turystów z Europy. Wstąpienie Polski do Unii Europejskiej w 2004 r. przyczyniło się do dalszego rozwoju wielu dziedzin gospodarczych, w tym również turystyki na poziomie lokalnym i ponadlokalnym. Dla rozwoju ww. funkcji gmin będących w strefie oddziaływania miasta centralnego konieczne jest prawidłowo funkcjonujące środowisko przyrodnicze oraz rozwinięta baza hotelowa i gastronomiczna. Duże znaczenie ma także rozwój połączeń komunikacyjnych i transportowych krajowych jak i międzynarodowych, w tym także połączeń lotniczych. Na terenie Poznania działa lotnisko Poznań-Ławica o rosnącej liczbie połączeń krajowych i międzynarodowych.

Czynniki ekologiczne odgrywają znaczącą rolę $\mathrm{w}$ kreowaniu funkcji turystycznych gmin. Jednak zarówno środowisko historyczne i zasoby kultury materialnej i dobrze działająca baza noclegowa i gastronomiczna wpływają na wzrost atrakcyjności oferty turystycznej. Szczególnie gminy Kórnik, Stęszew, Murowana Goślina i Pobiedziska, ze względu na atrakcyjne uwarunkowania przyrodnicze oraz dobrze rozwiniętą bazę noclegową i gastronomiczną, oraz bogatą ofertę kulturową, rozwinęły turystykę jako jedną z wiodących gałęzi gospodarczych. Wsie położone $\mathrm{w}$ okolicach jezior i kompleksów leśnych zmienily tradycyjne rolnictwo na agroturystykę. Oferują lokalne produkty spożywcze oraz wyroby rzemieślnicze stanowiące atrakcję dla obcokrajowców. Rozwój gospodarczy, w tym także turystyczny powiązany jest również $\mathrm{z}$ czynnikami społecznymi, które odgrywają istotną rolę $\mathrm{W}$ procesie transformacji. Także czynniki ekonomiczne wpływają znacząco na ww. proces, są silnie powiązane z funkcjami społeczno-gospodarczymi.

Rozwój turystyki, sportu i rekreacji w gminach powiatu poznańskiego zależy od uwarunkowań środowiska przyrodniczego, historycznego i zasobów kultury materialnej, od czynników ekologicznych, społecznych i ekonomicznych oraz od predyspozycji lokalnych społeczności i władz samorządowych do przemian i rozwoju.

\section{Bibliografia}

Borucińska-Bieńkowska H., Proces urbanizacji terenów wiejskich gmin powiatu poznańskiego, Politechnika Śląska, Gliwice 2016.

Borucińska-Bieńkowska H., Wpływ transformacji społeczno-gospodarczej aglomeracji na kierunki rozwoju gmin, Wydawnicza Uniwersytetu Zielonogórskiego, Zielona Góra 2013. Łęcki W., Przewodnik Wielkopolska, Sport i Turystyka Muza SA, Warszawa 1996.

Ustawa z27.03.2003 o planowaniu izagospodarowaniu przestrzennym. DzU nr 80, poz. 717. Ustawa z 27.04.2001 prawo o ochronie środowiska. DzU 08.25.150. 
Ustawa z 16.04.2004 o ochronie przyrody. DzU 09.151.1220.

Ustawa z 23.07.2003 o ochronie zabytków i opiece nad zabytkami. DzU 03.162.1568 z późn. zm.

Województwo Wielkopolskie. Podregiony, Powiaty, Gminy 2011. Urząd Statystyczny w Poznaniu, Poznań 2011.

Województwo Wielkopolskie. Podregiony, Powiaty, Gminy 2015. Urząd Statystyczny w Poznaniu, Poznań, 2015.

\section{Natural landscape areas and tourism development in communes of the Poznań county}

\section{Summary}

The article discusses areas of outstanding natural beauty protected by law playing an important role in shaping environmental systems of whole functional-spatial areas, which include a considerable part of animate and inanimate nature. In the Wielkopolska province, such areas constitute $35.6 \% \quad\left(29.826 \mathrm{~km}^{2}\right)^{7}$; they are national parks (Wielkopolski National Park), natural landscape parks and landscape protection areas. Besides, there are nature reserves and natural monuments, often situated in the abovementioned areas. The Wielkopolska province has $2.718 \mathrm{~m}^{2}$ of natural land protected by law per capita. These natural lands greatly influence standards of living of city and countryside dwellers, prospects of development, and extent, layout and structure of tourism movement. For many residents of rural communes situated within the impact zone of a big city, this particular type of economic activity is a vital part of socioeconomic development. Landscape protection areas, thanks to characteristic features of the landscape boasting various ecosystems, render it possible to pursue interests in tourism, sports and recreation; they can also function as ecological wildlife corridors. In communes of the Poznań Metropolitan Area (POM), there are all forms of environmental protection pursuant to the Environmental Protection Act of 16 April 2004 (consolidated text in the Journal of Laws of 2013, item 627 as amended). They do not form an integrated complementary network but are 'ecological islands', which poses a major problem for functional-s patial development of natural landscape areas, both protected by law and unprotected. The 'islands' greatly influence decisions taken by self-governmental authorities and local communities on shaping practical and rational policies of sustainable development of natural landscape areas, and they might adversely affect biological resilience of functional areas.

Translated by Kamila Korus

7 Województwo wielkopolskie - podregiony, powiaty, gminy 2015. Urząd Statystyczny w Poznaniu, Poznań 2015. 